\title{
China and India Trade Competition and Complementary: Analysis of the "Belt and Road" Background
}

\author{
Kangkang Li \\ School of Economics, Jinan University, Guangzhou, China \\ Email: 1554365929@qq.com
}

How to cite this paper: Li, K.K. (2018) China and India Trade Competition and Complementary: Analysis of the "Belt and Road" Background. Modern Economy, 9, 1213-1227.

https://doi.org/10.4236/me.2018.97079

Received: June 12, 2018

Accepted: July 20, 2018

Published: July 23, 2018

Copyright $\odot 2018$ by author and Scientific Research Publishing Inc. This work is licensed under the Creative Commons Attribution International License (CC BY 4.0).

http://creativecommons.org/licenses/by/4.0/

\section{(c) (i) Open Access}

\begin{abstract}
In recent years, bilateral relations between China and India are the focus of international attention. Despite the constant friction between China and India, the fact that China is the largest trade partner in India is not changed, and the bilateral trade volume in 2017 has set a new record of history. The continued implementation of the strategy of "One Belt and One Road" of the Chinese government has brought lots of new opportunities for China and India economic and trade cooperation. In order to analyze the competitiveness and complementarity of trade between China and India under the background of "One Belt and One Road", the article uses the "UN" UNCOMTRADE database, measuring the trade of China and India of revealed comparative advantage index, trade integration index, export similarity index, the specialization of the revised coefficient index and coefficient of consistent index, to analyze competition and complementarity of trade between China and India. Results show that the trade structure of China and India has a certain competition, but also has a lot of complementarity; There are many types of products in mutual trade: China mainly exports manufactured goods to India, and the India exports to China mainly primary products and semi-finished products. According to the strategy of "One Belt and One Road" background, we try to put forward policy measures to promote China's economic and trade relations with south India.
\end{abstract}

\section{Keywords}

“One Belt and One Road", Trade Competition, Trade Complementarity, China and India

\section{Introduction}

The Chinese government will promote the "One Belt and One Road" initiative. 
It will be included in the Party Constitution of the ruling party in China and will be demonstrated to the world the Chinese government's determination and confidence in strengthening the "One Belt and One Road" international cooperation. In the second half of 2013, President Xi Jinping proposed to the international community the strategic concept of jointly building the Silk Road Economic Belt and the 21st Century Maritime Silk Road for the first time, demonstrating to the world the grand blueprint of the "One Belt and One Road" initiative, which has received over 60 worldwide countries and regions' positive responses, including countries such as India in South Asia [1]. Historically, India is the most important meeting point for the Northern Silk Road, the Southern Silk Road, and the Maritime Silk Road. As a rising emerging power, India is an unavoidable existence in China's implementation of the "One Belt and One Road" strategy. In addition, the implementation of the "One Belt and One Road" strategy is in line with India's long-term interests, and India is also actively participating in the construction of the Bangladesh-China-Burmese Economic Corridor. India has seen rapid economic growth in recent years. Its performance has been outstanding, its national strength has been greatly enhanced, its influence in the region and the world has increased, and its economy has entered the fast lane of development. Observing the trade between China and India in 2016, India exported 8.92 billion dollars to China, a decrease of $6.89 \%$ compared to the last year, accounting for 3.43\% of India's total exports; India's import from China was 60.48 billion dollars, a decrease of $1.82 \%$ compared to the last year, accounting for $16.96 \%$ of India's total imports. Despite experiencing a series of events including the China-Pakistan Economic Corridor and other events, the trade between the two countries created a new historical record in 2017. Bilateral trade volume exceeded 80 billion dollars for the first time, amounting to 84.41 billion dollars, an increase of $18.63 \%$ over the same period of last year. And in 2016, the bilateral trade volume was only as much as 15 billion dollars. It can be seen that India plays a crucially strategic role in the smooth implementation of the "One Belt and One Road" [2]. The above data are derived from the "UN" UNCOMTRADE database.

\section{Literature Review}

One of the main aims of the "One Belt and One Road" is to conduct economy and trade cooperation and exchanges. This paper focuses on analyzing the current status and potential of China-India economy and trade cooperation in terms of competitiveness and complementarity. At present, the academic research on the "One Belt and One Road" has been gradually studied from the theoretical overview to the empirical analysis.

The article published by Zhang Jun is called Trade Relations between China and "One Belt and One Road" Areas-Based on An Empirical Analysis of Value-Added Trade Accounting during 2001-2013 in2014. He concludes that, from an international comparison point of view, the low proportion of local val- 
ue-added in exports in the industry is a major factor in China's overall value of local exports that is lower than that of the United States, Germany, and Japan, while the manufacturing sector with a low proportion of the local value-added industries in the export industry is the main factor in the lower value of the local value-added of the entire Chinese exports [3].

Zhang Huiqing (2017) studies on Trade Relations between China and "One Belt and One Road” Areas-An Analysis Based on Trade Intensity Index Model. Study has shown that since 2012, China has made significant progress in export trade along the Belt and Road Initiative, and exports to Southeast Asia and South Asia have been particularly prominent. In contrast, China's import trade along the Belt and Road Initiative has been slow. China has strong complementarity with the areas along the "One Belt and One Road" in the export trade of advantageous industrial products. At the same time, it has strong complementarities with the areas along the "One Belt and One Road" in the import trade of resource products [4].

Li Yingxu (2016) studies on the cooperation foundation, advancement opportunity and realization mechanism of trade between China and South Asia under the "One Belt and One Road" strategy. The study believes that there is a wide range of opportunities for trade cooperation between the two countries. China can make use of the complementarity with South Asian trade and take the opportunity of the "One Belt and One Road" strategy to implement interconnection, build a platform for economic and trade cooperation, expand investment, and strengthen regional trade system arrangements [5].

However, few articles have studied the trade between China and India in the context of the "One Belt and One Road". In view of this, this paper attempts to empirically analyze the economy and trade cooperation between China and India by using quantitative measurement methods based on the data of China-India related trade during 2003-2016 ("UN" UNCOMTRADE database data of 2017 not updated). To study the status and potential of trade between China and India, and provide implementation arguments for strengthening China-India trade cooperation, this paper attempts to start from the aspects of trade competitiveness and complementarity. This article studies the trade status and potential of China and India from the perspective of trade competitiveness and complementarity. Indicators used are the Trade Integration Index (TII), the Revealed Comparative Advantage Index (RCA), the Export Similarity Index (ESI), the Coefficient of Specialization (CS), and the Coefficient of Conformity (CC) to measure the trade competitiveness and complementarity between China and India [6].

This paper mainly uses the "UN" UNCOMTRADE database data from 2003 to 2016, adopting the SITC (Standard International Trade Classification) Revised Standards (Rev.3) statistics, some data are from the Customs Information Network. According to the United Nations classification of international trade standards, there are roughly three categories of international trade goods: re- 
source-intensive products, capital- and technology-intensive products, and labor-intensive products. Resource-intensive products include SITC0 (food and live animals), SITC1 (beverages and tobacco), SITC3 (mineral raw materials, lubricants and raw materials) and SITC4 (animal and vegetable oils, oils and waxes), that is primary products; capital and technology intensive products include SITC5 (chemical products and related products) and SITC7 (machinery and transport equipment); labor-intensive products include SITC6 (manufactured products by raw materials) and SITC8 (miscellaneous products); and finally SITC9 (others unclassified manufactured products).

\section{Overall Description of the Status of Trade between China and India}

\subsection{Scale of China's Import and Export Trade with India}

\subsubsection{China's Export Trade to India}

India is China's the largest export destination in Southeast Asia. In 2016, China's exports to India reached 60.48 billion dollars, accounting for $2.9 \%$ of China's total exports. In recent years, as China's export trade to India has continued to increase, in order to protect local companies, Indian government exerts pressure on enterprises entering India through anti-dumping and other trade measures, so bilateral trade frictions between China and India have also occurred. Among them, the impact on Chinese companies is particularly severe, so the growth rate of Chinese exports to India fluctuates greatly. Data about bilateral trade between China and India are shown in Table 1.

Due to trade friction and other issues, the growth rate of bilateral trade between China and India fluctuated considerably. The 2010-2016 China-India import and export data are selected to analyze the status. In 2010, China's exports to India were 41.25 billion dollars, an increase of $34.76 \%$ year-on-year. In 2011 , China's exports to India were 55.48 billion dollars, an increase of $34.5 \%$. In 2012, China's exports to India were 54.14 billion dollars, a year-on-year decline rate of $2.42 \%$, and we can see the growth rate fluctuates greatly. Since 2012 , the scale of

Table 1. Scale of bilateral trade between China and India (2010-2016, unit: \$100 million).

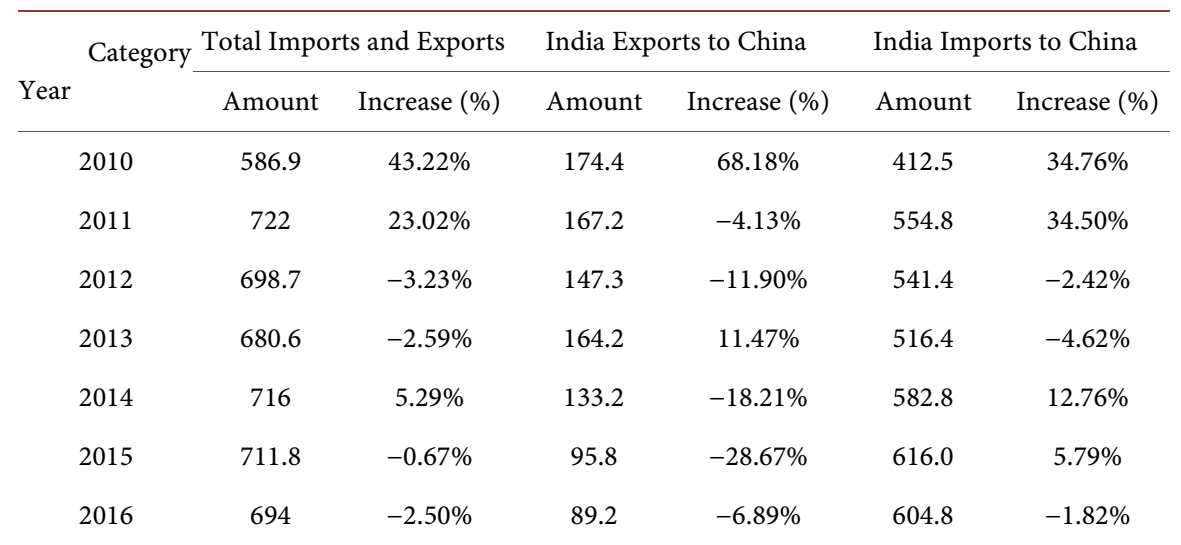

Data resource: “UN" UNCOMTRADE database. 
China's exports to India had rising again, indicating that China's trade cooperation with India was becoming more and more harmonious. The scale of China's exports to India will also gradually increase with the continuous strengthening of trade cooperation between China and India.

\subsubsection{India's Export Trade to China}

China is a major exporter of India. In 2016, India's exports to China reached 8.92 billion dollars, accounting for $3.43 \%$ of India's total exports. Due to the similar trade structure of China and India, the two countries showed strong competition in the international market. In addition, the unbalanced trade development between China and India in recent years has led to a larger fluctuation of growth rate of India's exports to China. Meanwhile, since 2011, the scale of India's exports to China had shown a downward trend, and India's exports to China accounted for the proportion of India's total exports had also been declining.

\subsection{Structure of China's Import and Export Trade with India}

Since the cooperation between China and India, China's exports to India have been dominated by manufactured goods, while India's exports to China have been mainly on primary or semi-finished products. In recent years, the bilateral trade structure between China and India has undergone great changes with the improvement of the economic level of the two countries. The types of trade products between the two countries have increased significantly, and the trade volume of manufactured goods has also shown an upward trend. The relevant data of 2014-2016 is selected here to analyze the bilateral trade structure between China and India by Table 2.

China's products imported from India mainly include cotton, copper and its products, mineral products, jewelry precious metals and products, and organic chemicals. According to the latest statistics from the China Customs Information Network, China imported $\$ 3.218$ billion worth of cotton from India in 2014, accounting for $19.66 \%$ of China's total imports from India. In addition,

Table 2. Structure of China's import trade from India (2014-2016, Unit: \$100 million).

\begin{tabular}{|c|c|c|c|c|c|c|}
\hline \multirow{2}{*}{$\begin{array}{ll} & \text { Years } \\
\text { Category } & \end{array}$} & \multicolumn{2}{|c|}{2014} & \multicolumn{2}{|c|}{2015} & \multicolumn{2}{|c|}{2016} \\
\hline & Amount & $\begin{array}{c}\text { Proportion } \\
(\%)\end{array}$ & Amount & $\begin{array}{c}\text { Proportion } \\
(\%)\end{array}$ & Amount & $\begin{array}{c}\text { Proportion } \\
(\%)\end{array}$ \\
\hline Cotton & 32.18 & 19.66 & 22.75 & 17.00 & 12.69 & 10.79 \\
\hline $\begin{array}{l}\text { Copper and its } \\
\text { products }\end{array}$ & 23.42 & 14.31 & 16.47 & 12.31 & 10.00 & 8.51 \\
\hline Mineral products & 25.03 & 15.29 & 18.75 & 14.01 & 21.64 & 18.41 \\
\hline $\begin{array}{c}\text { Jewelry, precious } \\
\text { metals and } \\
\text { products }\end{array}$ & 25.23 & 15.41 & 19.61 & 14.65 & 24.95 & 21.22 \\
\hline Organic chemicals & 10.59 & 6.47 & 11.02 & 8.23 & 9.1 & 7.74 \\
\hline
\end{tabular}

Data resource: “UN” UNCOMTRADE database. 
China's imports of copper and its products, mineral products, jewelry precious metals and products, organic chemicals were respectively 2.342 billion dollars, 2.503 billion dollars, 2.523 billion dollars, and 1.059 billion dollars, accounting for $14.31 \%, 15.29 \%, 15.41 \%$, and $6.47 \%$ of China's total imports from India. Meanwhile, China's imports from India also include animal and vegetable oils, plastics and their products, leather, machinery and electrical and mechanical equipment. India's imports from China are mainly divided into six categories, including organic chemicals, fertilizers, plastics and their products, iron and steel products, and mechanical and electrical products and machinery and equipment. In 2014, India's imports of these six categories of goods from China were respectively $\$ 6.241$ billion, $\$ 2.339$ billion, $\$ 2.541$ billion, $\$ 3.875$ billion, $\$ 10.067$ billion, and $\$ 109.80$ billion, and the total amount was $\$ 36.143$ billion, accounting for $66.47 \%$ of India's total imports from China. In addition to the above products, India has also imported other goods from China, such as transportation equipment like vehicles, mineral materials, furniture and textiles.

In 2015, China's imports of cotton from India declined, whose value was $\$ 2.275$ billion, a decrease of $29.30 \%$, but still accounted for $17 \%$ of China's total imports from India; In addition, compared to 2014, China's imports of copper and products, minerals, jewellery, precious metals and products all decreased, imports were $\$ 1.647$ billion, $\$ 1.875$ billion, $\$ 1.961$ billion and $\$ 1.647$ billion, down by $29.30 \%, 29.68 \%$ and $25.09 \%$ respectively. Only imports of organic chemicals increased compared to 2014 , with imports being $\$ 1.102$ billion, an increase of $4.1 \%$. The above four imports accounted for $12.31 \%, 14.01 \%, 14.65 \%$ and $8.23 \%$ of China's total imports from India respectively. In addition, Chinese imports from India include animal and vegetable oils, plastics and their products, raw skins (except furs) and leather, mechanical apparatus and parts, audio and video equipment and their accessories, and steel and their products. India's imports from China are mainly divided into five categories, including organic chemicals, fertilizers, iron and steel and their products, mechanical apparatus and parts, mechanical and electrical products. In 2015, India's imports of these five categories of goods from China amounted to $\$ 5.95$ billion, $\$ 3.541$ billion, $\$ 3.67$ billion, $\$ 10.2$ billion and $\$ 13.382$ billion respectively. The total amount was $\$ 36.743$ billion, accounting for $63.09 \%$ of India's total imports from China. In addition to the above-mentioned five categories of products, India had a lot of goods imported from China, such as plastics and their products, vehicles and other transportation equipment, mineral materials, furniture and textiles.

In 2016, China's total value of cotton imported from India was 1.269 billion dollars, accounting for $10.79 \%$ of China's total imports from India, down by 44.22\%; China's imports of copper and its products, minerals, jewelry precious metals and products, and organic chemicals were $\$ 1$ billion, $\$ 2.164$ billion, $\$ 2.495$ billion and $\$ 910$ million respectively, accounting for $8.51 \%, 18.41 \%$, $21.22 \%$, and $7.74 \%$ of China's total imports from India. Compared to last year, copper and products, minerals and organic chemicals were down by $39.28 \%$ and 
$15.41 \%$, and $17.42 \%$ respectively. Only jewelry, precious metals and products rose $27.23 \%$.

China's imports of cotton and copper and its products from India fell by a large margin, with a decrease of $44.22 \%$ and $39.28 \%$. China's imports from India include animal and vegetable oils, plastics and their products, raw hides (except fur) and leather, machinery and audio-visual equipment. India's imports from China are mainly divided into four categories, specifically mechanical apparatus and parts, audio and video equipment and its accessories, chemical products and base metals and products. In 2016, India's imports of these four categories of goods from China were $\$ 10.367$ billion, $\$ 16.9$ billion, $\$ 9.127$ billion, and $\$ 4.626$ billion, which accounted for $17.75 \%, 28.94 \%, 15.63 \%$, and 7.92 of India's total imports from China respectively.

In general, Chinese imports from India are mainly on cotton, copper and its products, mineral products, jewelry precious metals and products, as well as organic chemicals. On the other hand, India imports a lot of goods from China, mainly including mechanical apparatus and parts, audio and video equipment and accessories, chemical products, pharmaceuticals, textiles, plastics and their products, and paper pulp. In recent years, the structure of India's imports from China has changed significantly. In the past, mineral products were the second largest product imported by India from China. In recent years, machinery, audio-visual equipment and chemical products have leaped to the first, second and third largest imports from China, with mineral products falling sharply.

\section{The Trade Complementarity between China and India}

\subsection{Revealed Display Comparative Advantage Index}

The Revealed Comparative Advantage (RCA) index is the most convincing indicator of the competitiveness of a country's products or industries in the international market. It is generally expressed by the ratio of the share of the industry in the export of the country to the share of the total world trade in the world trade. It is an index to measure the comparative advantage of a certain country or region in the trade of a certain industry. Due to the elimination of the impact of the fluctuation of the total amount of the country and the impact of the fluctuation of the total volume of the world, it can better reflect the comparative advantage of a country's exports compared with the average export level of the world [7]. The calculation formula is $R C A=\frac{X_{a}^{i} / X_{a}}{X_{w}^{i} / X_{w}}, X_{a}^{i}$ represents the export value of the export product $i$ of the country $a, X_{a}$ represents the total export value of the country $a, X_{w}^{i}$ represents the export value of the product $i$ of the world, and $X_{w}$ represents the total export value of the world. Generally speaking, there are four situations. When the RCA index of an industry in a country is greater than 2.5 , it means that the country's industry has extremely strong international competitiveness in the international market; when a country's RCA is between 2.5 and 1.25, it indicates that the country's industry has 
very strong international competitiveness in the international market; When the RCA of a country's industry is between 1.25 and 0.8 , it considers that the country's international competition in the international market is strong; when RCA of a country's industry is less than 0.8 , it indicates that the country's industry has a comparative disadvantage in the international market.

As can be seen from Table 3, since 2006, the Revealed Comparative Advantage index of China's SITC7 (Machinery and Transportation Equipment) has exceeded 1.25, indicating that China's comparative advantage in manufacturing has been continuously enhanced, and capital and technology products already have strong international competitiveness, which is consistent with China's position as a manufacturing country, has also been related to China's role as a global processing factory. In recent years, as a representative of China's high-end equipment manufacturing industry, China's high-speed rail frequently "goes abroad and goes to the world". According to statistics, nearly 30 countries in the world have negotiated with China about the introduction of high-speed rail technology or cooperative development, which is the proof of the outstanding achievements of China's manufacturing industry. The RCA index shows that China's competitiveness in primary products is relatively weak and shows a trend of decreasing year by year, including SITC0 (food and live livestock), SITC1 (beverages and tobacco), SITC2 (non-edible raw materials), and SITC3 (fossil fuels, lubricants, and raw materials), SITC4 (animal and vegetable oils), the reason is that China is a populous country with low per-capital possession of natural resources and a huge amount of consumption, so it has no comparative advantage in resource-intensive products. However, China has obvious advantages in labor-intensive products, including SITC6 (manufactured products by raw materials) and SITC8 (miscellaneous products), especially SITC8 products have strong international competitiveness of over 2.5, but since 2003 the overall

Table 3. China’s RCA index.

\begin{tabular}{cccccccccccccccc}
\hline Years & 2003 & 2004 & 2005 & 2006 & 2007 & 2008 & 2009 & 2010 & 2011 & 2012 & 2013 & 2014 & 2015 & 2016 \\
Category & & & & & & & & & & & & & & & \\
\hline SITC0 & 0.72 & 0.60 & 0.58 & 0.55 & 0.50 & 0.44 & 0.44 & 0.46 & 0.46 & 0.44 & 0.42 & 0.40 & 0.41 & 0.45 \\
SITC1 & 0.25 & 0.24 & 0.19 & 0.16 & 0.15 & 0.14 & 0.16 & 0.16 & 0.16 & 0.16 & 0.15 & 0.15 & 0.17 & 0.19 \\
SITC2 & 0.38 & 0.32 & 0.31 & 0.24 & 0.21 & 0.23 & 0.20 & 0.18 & 0.18 & 0.17 & 0.17 & 0.18 & 0.18 & 0.18 \\
SITC3 & 0.27 & 0.24 & 0.19 & 0.13 & 0.13 & 0.14 & 0.13 & 0.12 & 0.11 & 0.09 & 0.10 & 0.11 & 0.12 & 0.17 \\
SITC4 & 0.06 & 0.06 & 0.09 & 0.10 & 0.06 & 0.07 & 0.05 & 0.05 & 0.05 & 0.05 & 0.05 & 0.06 & 0.06 & 0.05 \\
SITC5 & 0.42 & 0.42 & 0.44 & 0.45 & 0.47 & 0.53 & 0.45 & 0.50 & 0.56 & 0.52 & 0.50 & 0.53 & 0.51 & 0.51 \\
SITC6 & 1.15 & 1.21 & 1.22 & 1.28 & 1.25 & 1.34 & 1.22 & 1.22 & 1.28 & 1.31 & 1.34 & 1.35 & 1.37 & 1.34 \\
SITC7 & 1.08 & 1.15 & 1.21 & 1.25 & 1.28 & 1.37 & 1.43 & 1.44 & 1.45 & 1.42 & 1.42 & 1.32 & 1.28 & 1.23 \\
SITC8 & 2.33 & 2.23 & 2.20 & 2.22 & 2.21 & 2.26 & 2.13 & 2.17 & 2.25 & 2.35 & 2.33 & 2.22 & 2.02 & 1.97 \\
SITC9 & 0.05 & 0.04 & 0.06 & 0.06 & 0.04 & 0.03 & 0.02 & 0.02 & 0.02 & 0.01 & 0.01 & 0.02 & 0.02 & 0.02 \\
\hline
\end{tabular}

Data resource: "UN" UNCOMTRADE database. 
showed a downward trend. In a word, China's comparative advantage in capital-or technology-intensive products is gradually growing, the comparative advantage in labor-intensive products is evident and continues to be maintained, but China is not competitive on resource-intensive products. This is in line with China's abundant labor resources and the relative lack of natural resources and capital factor endowment.

From Table 4, we can see that India has a strong revealed comparative advantage in SITCO (food and live animals), SITC2 (non-edible raw materials), SITC6 (manufactured products by raw materials) and SITC8 (miscellaneous products) among the 10 categories of products classified by the United Nations International Trade Standards. From 2003 to 2016, SITCO (food and live animals) showed a comparative advantage index of more than 1.25 (except for 2009-2010), showing a downward trend and then a rising trend. Before 2012, the revealed comparative advantage index of SITC2 was always greater than 1.25, but the revealed comparative advantage index of SITC2 showed an opposite trend, with the trend of rising first and then decreasing. From 2003 to 2016, the revealed comparative advantage index of SITC6 fluctuated greatly, falling first and then rising, from extremely strong competitiveness to very strong competitiveness, but still has obvious advantages. The revealed comparative advantage index of SITC1, SITC7 and SITC9 were all less than 0.8, indicating that the above three products were at a comparative disadvantage.

In recent years, India has experienced twists and turns on SITC8 (miscellaneous products), and its competitiveness has declined and risen alternately, but it still maintain a strong international competitiveness.

\subsection{Trade Integration}

The Trade Integration Index (TII) is used to measure the degree of integration of Table 4. India's RCA index.

\begin{tabular}{|c|c|c|c|c|c|c|c|c|c|c|c|c|c|c|}
\hline Category & 2003 & 2004 & 2005 & 2006 & 2007 & 2008 & 2009 & 2010 & 2011 & 2012 & 2013 & 2014 & 2015 & 2016 \\
\hline SITC0 & 1.77 & 1.72 & 1.56 & 1.57 & 1.60 & 1.66 & 1.10 & 1.24 & 1.34 & 1.59 & 1.66 & 1.61 & 1.58 & 1.52 \\
\hline SITC1 & 0.45 & 0.45 & 0.42 & 0.44 & 0.45 & 0.58 & 0.65 & 0.59 & 0.43 & 0.50 & 0.50 & 0.47 & 0.52 & 0.53 \\
\hline SITC2 & 1.38 & 1.97 & 2.34 & 2.08 & 2.11 & 1.91 & 1.65 & 1.73 & 1.25 & 1.59 & 1.19 & 1.05 & 1.02 & 1.0 \\
\hline SITC3 & 0.65 & 0.79 & 0.85 & 1.07 & 1.27 & 1.10 & 1.03 & 1.20 & 1.18 & 1.16 & 1.29 & 1.48 & 1.16 & 1.43 \\
\hline SITC4 & 0.83 & 1.11 & 0.91 & 0.75 & 0.68 & 0.63 & 0.64 & 0.67 & 0.64 & 0.59 & 0.62 & 0.60 & 0.77 & 0.67 \\
\hline SITC5 & 1.08 & 1.09 & 1.07 & 1.13 & 1.06 & 1.08 & 0.91 & 0.97 & 0.96 & 1.11 & 1.09 & 1.08 & 1.22 & 1.24 \\
\hline SITC6 & 2.80 & 2.48 & 2.41 & 2.16 & 2.04 & 1.99 & 1.96 & 2.19 & 1.91 & 1.86 & 2.01 & 1.90 & 2.06 & 2.09 \\
\hline SITC7 & 0.24 & 0.25 & 0.27 & 0.29 & 0.30 & 0.39 & 0.45 & 0.42 & 0.42 & 0.41 & 0.41 & 0.44 & 0.45 & 0.44 \\
\hline SITC8 & 1.51 & 1.55 & 1.45 & 1.44 & 1.30 & 1.15 & 1.55 & 1.12 & 1.24 & 1.35 & 1.03 & 1.12 & 1.18 & 1.28 \\
\hline SITC9 & 0.35 & 0.27 & 0.30 & 0.28 & 0.27 & 0.35 & 0.77 & 0.40 & 0.92 & 0.18 & 0.42 & 0.20 & 0.62 & 0.38 \\
\hline
\end{tabular}

Data resource: “UN” UNCOMTRADE database. 
trade between the two countries. The larger the value is, the closer the trade union is and the stronger the trade complementarity is. The formula is that $T I I=\frac{E_{a b} / E_{a}}{M_{b} / M_{w}}$, and $E_{a b}$ represents the amount of exports from country a to country b over a period of time, $E_{a}$ represents the total exports of country a during this period, $M_{b}$ represents the total imports of country b during this period, and $M_{w}$ represents the total imports amount of the world during this period of time. When the TII is greater than 1 , it shows that the trade relations between the two countries are closely linked; when the TII is less than 1, it indicates that the trade relations between the two countries are loosely linked.

According to Table 5, the degree of China's Trade Integration with India is greater than the degree of India's Trade Integration with China. The share of China's exports to India in total exports is far lower than the share of India's exports to China in its total exports. Say concretely, the degree of trade integration between China and India shows the same trend of rising first and then descending. India's trade integration with China is roughly less than 1 . China is less dependent on the Indian market and its trade relations are relatively loose, with trade dependence alone exceeded 1 in 2005, and then showed a downward trend. China's trade integration with India is greater than or close to 1, indicating that India has a certain dependence on the Chinese market, but in recent years the degree of trade integration has been decreasing, indicating that India's degree of trade dependence on China is weakening.

\subsection{Trade Complementarity}

This paper uses the Coefficient of Specialization (CS) and the Coefficient of Conformity $(C C)$ as the evaluation methods to analyze the trade complementarity between China and India. The Computational Complementarity Index $(C I)$ is calculated as:

$$
\begin{gathered}
C S=1-\frac{1}{2} \sum_{n}\left|a_{t}^{n}-b_{t}^{n}\right| \\
C C=\frac{\sum_{n} a_{t}^{n} b_{t}^{n}}{\sqrt{\sum_{n}\left(a_{t}^{n}\right)^{2} \sum_{n}\left(b_{t}^{n}\right)^{2}}} \\
C I=\frac{C S+C C}{2}
\end{gathered}
$$

Table 5. China-India bilateral trade integration index (TII).

20032004200520062007200820092010201120122013201420152016

India vs. China 0.7970 .8931 .1370 .9890 .9470 .7890 .7210 .8530 .5700 .4950 .4510 .3910 .3480 .319

China vs. India $0.8010 .9380 .8721 .0231 .2551 .1261 .145 \quad 1.1151 .0310 .8420 .8480 .9111 .0591 .152$

Data resource: "UN" UNCOMTRADE database. 
Among them, $a_{t}^{n}$ means that the export value of product $n$ in country $a$ during the period of $t$ time accounts for the proportion of its total export value, $b_{t}^{n}$ means that the import value of product $n$ in country $b$ during the period of $t$ time accounts for the proportion of its total import value. The closer the Index is to 1 , the stronger the trade complementarity between the two countries and the greater the opportunities for trade cooperation is [8]. The trade complementarity between China and India is shown in Table 6.

As can be seen from the trade complementarity CI index (Table 6), the CI index exceeds 0.6 , indicating that the trade complementarity of the two countries is very strong. China's imports from India are mainly raw materials such as base metals and products, mineral products and textiles, while India's imports from China are mainly mechanical equipment, audio and video equipment, chemical products and transportation equipment and other industrial products, China and India are different in the structure of trade commodity, with a certain degree of complementarity. In recent years, the top three export products of China are SITC6 (manufactured products by raw materials), SITC7 (machinery and transport equipment) and SITC8 (miscellaneous products), which together account for $88 \%$ of China's total exports and above. India's top three imports in recent years are SITC3 (mineral raw materials, lubricants and raw materials), SITC6 (manufactured products by raw materials), and SITC7 (machinery and transport equipment), which together account for more than 65\% of India's total imports. That is, SITC6 and SITC7, the two categories of products with the highest proportion of China's exports happen to be India's main imports; On the other hand, SITC3, which ranks third in China's import share (with an average import share of over 14\%), is India's main export product, with an average export proportion of more than $19 \%$ of India. It can be seen that the export structure and import structure of China and India are very similar, thus the two countries have trade complementarity in a certain and great potential for trade cooperation.

\section{Analysis of Trade Competition between China and India}

\subsection{Similarity in Exports}

The Export Similarity Index (ESI) is used to measure the degree of similarity between the two countries in the structure of export commodity to a common target market. The calculation formula is

$E S I_{a b}=\left\{\sum_{i=0}^{n}\left[\frac{1}{2}\left(X_{a}^{i} / X_{a}+X_{b}^{i} / X_{b}\right) \times\left(1-\left|\frac{X_{a}^{i} / X_{a}-X_{b}^{i} / X_{b}}{X_{a}^{i} / X_{a}+X_{b}^{i} / X_{b}}\right|\right)\right]\right\} \times 100, X_{a}^{i}$

Table 6. Trade complementarity index between China and India (CI).

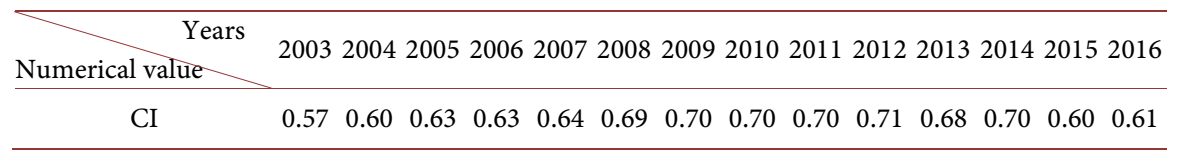

Data resource: “UN” UNCOMTRADE database. 
represents the export value of product $i$ in country $a, X_{a}$ represents the total export value of country $a$ to the world market, $X_{b}^{i}$ represents the export value of product $i$ in country $b$, and $X_{b}$ represents the total export value of country $b$ to world market, ESI measures the trade competitiveness by calculating the similarity between the two countries' exports in the face of world markets. The ESI index is from 1 to 100 . The larger the ESI index, the higher the export similarity between the two countries and the more fierce the trade competitiveness. China and India export similarity index as Table 7.

The similarity of exports between China and India shows an overall downward trend, but there has been a rise in volatility in recent years. The reason for the analysis is that China and India are both emerging developing countries, and their economic division of labor in the international market is similar, and they are also quite similar in terms of resource endowment, technological level and geographical location, forming a labor-intensive export industry, resulting in a high degree of similarity in export structure. China is in the process of transition from a big agricultural country to an industrial country. Now India is also actively transforming into capital and technology-intensive industries, which is bound to cause more intense competition between China and India in export trade.

\subsection{Trade Strategy}

Considering factors such as geopolitics, India is also on the road to rejuvenating its strong country and proposes its own peripheral development strategies, such as the Spice Road Program and the Monsoon Plan. In particular, the "Monsoon Plan" launched by the Modi government in 2014 is based on the history of trade in the countries around the Indian Ocean region, and India as the main force to jointly develop marine resources and strengthen economic and trade cooperation among Indian Ocean countries. The "Monsoon Plan" involves 39 Indian Ocean countries. The plan overlaps with the "Belt and Road Initiative" in China. As some people in India hold the one-sided mistaken thinking of "who leads and who profits" in the regional development strategy, the "Spicy Road Initiative" and the "Monsoon Plan" are partially regarded as India's "countermeasure" measures favorable to China's "Silk Road Economic Belt" and "21st Century Maritime Silk Road". They think that India will use its own regional development strategy to compete with China's "Belt and Road Initiative" to maximize the benefits.

Table 7. China-India export similarity index (ESI).

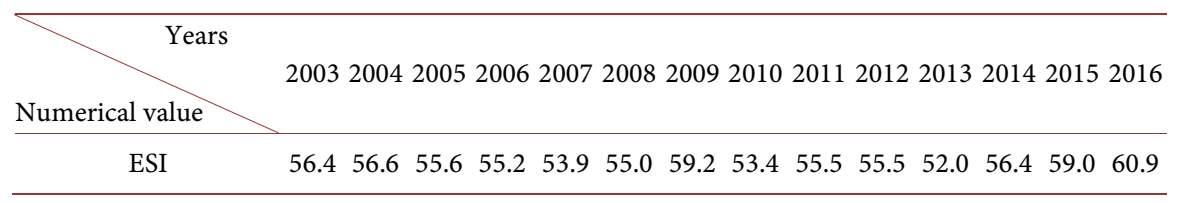

Data resource: "UN" UNCOMTRADE database. 


\section{Conclusions and Suggestions}

According to the analysis of this article, the trade competitiveness and complementarity of China and India coexist, and there are many kinds of trade products between them. China mainly exports manufactured goods to India and imports mainly primary and semi-finished products from India. The overall volume of trade between China and India in general is growing, and China has become India's major trading partner. From a global perspective, the export similarity between China and India has been increasing in recent years. The two countries have high export similarities and fierce competition. India is the most important country in South Asia, and the trade between China and India is highly complementary and stable. Under the trend of increasing competitiveness in recent years, China should make full use of the trade complementarity between the two parties and strengthen the trade of products with comparative advantage. With the implementation of the "One Belt and One Road", the economic and trade cooperation between China and India faces more opportunities and challenges. Therefore, measures should be taken to further expand trade cooperation and expand the field of international economic and trade cooperation.

\subsection{Utilize Trade Complementarity to Improve the Foreign Trade Structure}

China should strengthen its exports of products with comparative advantages and expand the trade of complementary products. From the previous empirical analysis, it can be found that although China and India have a certain degree of competition in labor-intensive products, there is still a large room for complementation in resource-intensive and capital-intensive products. The existence of certain competition in the trade between the two countries is unavoidable, and a reasonable competitive relationship can also promote the upgrading of the industrial structure and technological progress of the two countries [9]. Our country should expand exports of high-tech and high-value-added technology and capital-intensive products, reduce the export of labor-intensive products with low value-added, avoid excessive competition with India, and achieve a dynamic trade balance.

\subsection{Seek Common Interests and Link Regional Development Strategies}

Although both China and India have put forward their own regional development strategies, we have found that both the affected areas and the development routes are basically the same, the goals and benefits are common, there is no phenomenon of mutual competition, and one of the key themes of the "One Belt and One Road" initiative is "through", that is, to promote the interconnection between China and the countries along the Silk Road with the infrastructure as the main line, which happens to coincide with India's development needs. Therefore, China and India should uphold the principles of openness, tolerance 
and cooperation, equality and mutual benefit, seeking common ground while reserving differences, actively establish a friendly negotiation and negotiation mechanism, and link up with the regional development strategies of the two countries so as to seek a win-win situation for the rejuvenation of the two countries..

\subsection{Strengthen Trade Negotiations and Promote the Establishment of Free Trade Zone}

The Free Trade Zone is a new strategic platform for China to carry out the comprehensive opening up and reforms, and it plays a prominent role in expanding the scale of international trade, facilitating the operation of international logistics, and implementing new economic policies, affecting the future trend of international economic cooperation and regional trade pattern [10]. The establishment of the China-India Free Trade Zone should seize the opportunity to catch up with the "One Belt and One Road" initiative to strengthen the trade negotiation and cooperation between China and India, reduce trade barriers, reduce trade frictions, and strive to promote the establishment of the China-India Free Trade Zone as soon as possible.

\section{References}

[1] Chen, Z.X. and Xu, S. (2018) Competitiveness and Complementarity between China and South Asian countries in the Context of the "Belt and Road Initiative". Journal of South China Normal University (Social Sciences), No. 1, 110-117+191.

[2] Du, X.H. (2015) Analysis of Trade Structure of Goods between China and India in the Context of "One Belt and One Road": 2002-2014. Auditing and Economic Research, 30, 106-112.

[3] Luo, C.Y. and Zhang, J. (2014) Value-Added Trade: Empirical Analysis Based on China. Economic Research, 49, 4-17+43.

[4] Zhang, H.Q. and Tang, H.Y. (2017) Research on the Trade Relations between China and the "Belt and Road" Area-Based on the Analysis of Trade Intensity Index Model. International Economics and Trade Research, 33, 27-40.

[5] Li, Y.X. (2016) The Cooperation Foundation, Advancement Opportunity and Realization Mechanism of Trade between China and South Asia under the "One Belt and One Road" Strategy. Gansu Social Sciences, No. 2, 128-133.

[6] Sang, B.C. and Li, J.G. (2011) Expanding China's Trade Relations with Major Emerging Market Countries: An Analysis Based on Competitiveness and Complementarity of Trade. Finance \& Trade Economics, No. 10, 69-74+135-136.

[7] Han, Y.H., Luo, X.F. and Zou, J.H. (2015) Research on Competitiveness and Complementarity of Trade Cooperation between China and West Asia: Taking "One Belt and One Road” Strategy as Background. World Economic Research, No. 3, $89-98+129$.

[8] Liao, M.Z. (2015) China's Measurement of Commodity Export Potential of Countries along the Belt and Road Initiative. Open Herald, No. 3, 64-67.

[9] Xiao, Y. (2017) Empirical Analysis of China-India Bilateral Trade Relations under the Belt and Road Initiative. Chinese Business Theory, No. 14, 67-70. 
[10] Chen, J.Y., Jiang, Y.P. and Wang, B.S. (2017) China's Trade Competitiveness with Countries along the Belt and Road Initiative: A Double Perspective Based on Product Domain and Market Domain. World Economic Research, No. 8, 3-14+135. 